DOI: 10.19195/0137-1150.167.16

\author{
LUDMIŁA ŁUCEWICZ
}

Uniwersytet Warszawski, Polska

\title{
„Есть ли в моей жизни такой смысл, который не уничтожался бы неизбежно предстоящей мне смертью?”' (Исповедальные размышления Льва Толстого о смерти)
}

Смерть в ее онтологическом, экзистенциальном и социокультурном измерении неизменно присутствует в сознании человечества. Мортальность как специфическая философско-этическая проблема начинает привлекать внимание русских авторов во второй половине XVIII века и заметно актуализируется в конце XIX-начале XX веков ${ }^{2}$.

Роль Льва Толстого (1828-1910) как в плане непосредственной постановки и осмысления этой проблемы, так и в плане инспираций и разнообразных интерпретаций, связанных с ней, необычайно важна. Семен Франк отмечал, что „исходным пунктом и мотивом всего мировоззрения Толстого

1 Л. Н. Толстой, Исповедь, [в:] его же, Собрание сочинений в 22 m., т. 16, Москва 1983, c. 122. Далее после цитирования данного издания в тексте в скобках указываются номер тома и номер страницы.

2 См.: К. Г. Исупов, Русская философская танатология, „Вопросы философии” 1994, № 3, с. 106-114; его же, Русская философия смерти (ХVIII-ХХ в6.), [в:] Русская философия смерти: антология, сост., вступ. ст., коммент. его же, Москва-Санкт-Петербург 2012, с. 6-30; его же, Чары троянского наследия: Лев Толстой в пространствах приязни и неприятия, [в:] Лев Николаевич Толстой, ред. А. А. Гусейнов, Т. Г. Щедрина, Москва 2014, с. 9-34; А. Демичев, Дискурсы смерти. Введение в философскую танатологию, Санкт-Петербург 1997; В. Минеев, Социальные аспекты смерти (философско-антропологический анализ), Москва 2014; Р. Красильников, Танатологические мотивы в художественной литературе (Введение в литературоведческую танатологию), Москва 2015; Мортальность в литературе и культуре, ред. А. Г. Степанов, В. Ю. Лебедев, Москва 2015. 
был страх смерти”з; Федор Степун уточнял: „Его страх был возмущением и протестом против смертности человека"4; Петр Бицилли прямо указывал: ,[...] предметом, на который неизменно была устремлена душа Толстого, была - смерть - не как метафизически случайный, хоть и неизбежный конец жизни [...] но как ее завершение и ее отрицание".5.

Вопросы жизни и смерти, философская, этическая и художественная танатология в литературном наследии Толстого рассматривались в трудах русских религиозных философов ${ }^{6}$, отчасти в работах толстоведов советского периода ${ }^{7}$, в значительной степени в диссертациях и статьях современных авторов ${ }^{8}$. При этом предметом изучения становились прежде всего

${ }^{3}$ С. Л. Франк, Памяти Льва Толстого (1910), [в:] Л. Н. Толстой: pro et contra, Личность и творчество Льва Толстого в оценке русских мыслителей и исследователей, сост., вступ. ст., ком. и библиогр. К. Г. Исупова, Санкт-Петербург 2000, с. 550.

${ }^{4}$ Ф. А. Степун, Религиозная трагедия Льва Толстого (1922), [в:] Л. Н. Толстой: pro et contra..., c. 447.

${ }^{5}$ П. Бицилли, Проблема смерти в творчестве Толстого, [в:] Л. Н. Толстой: pro et contra..., c. 473.

${ }^{6}$ См.: Д. С. Мережковский, Л. Толстой и Достоевский, изд. подгот. Е. А. Андрущенко, Москва 2000; Л. Шестов, Откровения смерти. (Последние произведения Л. Н. Толстого), „Современные Записки” 1920, № 1 (Париж), с. 81-123; Н. Бердяев, Ветхий и Новый Завет в религиозном сознании Л. Толстого, [в:] Л. Н. Толстой: pro et contra..., с. 243263; С. Н. Булгаков, Человекобог и человекозверь. По поводу последних произведений Л. Н. Толстого: „Дьявол” и „Отеи Сергий”, [в:] Л. Н. Толстой: pro et contra..., с. 601-638; В. В. Зеньковский, Проблема бессмертия у Л. Н. Толстого, [в:] О религии Льва Толстого, Москва 1912, с. 27-58; В. Н. Ильин, Миросозериание графа Льва Николаевича Толстого и его место в истории философии ХІХ века, предисл., коммент. К. Г. Исупов, Санкт-Петербург 2000.

7 Л. Д. Опульская, Позднее творчество Л. Н. Толстого, [в:] Л. Н. Толстой, сост. А. И. Шифман, ред. Д. Д. Благой, Москва 1955, с. 336-367; Б. Эйхенбаум, Лев Толстой: семидесятые годы, Ленинград 1960; Б. Мейлах, Уход и смерть Льва Толстого, МоскваЛенинград 1960; В. Шкловский, Лев Толстой, Москва 1963; Г. Галаган, Путь Толстого к „Исповеди”, „Русская литература” 1978, № 3, с. 23-42.

${ }^{8}$ См.: Н. Хагурова, Проблема смысла жизни и смерти в философии Л. Н. Толстого, Автореферат на соискание ученой степени кандидата философских наук, Москва 1995; К. А. Нагина, Образно-смысловая оппозииия „жжизь”-, смерть” в произведениях Л. Н. Толстого 1880-х годов, Автореферат на соискание ученой степени кандидата филологических наук, Воронеж 1998; С. Меситова, Этическая танатология Л. Н. Толстого: Толстовский опыт переживания смерти и его нравственно-религиозный смысл, Автореферат на соискание ученой степени кандидата филологических наук, Тула 2003; Ю. Семикина, Художественная танатология в творчестве Л. Н. Толстого 1850-1880-х г2.: Образы и мотивы, Автореферат на соискание ученой степени кандидата филологических наук, Волгоград 2002; Г. Попов, Проблема жизни и смерти в религиозно-философской антропологии Л. Н. Толстого, Автореферат диссертации на соискание ученой степени доктора философских наук, Москва 2006; Н. Волохова „Путь смерти” Л. Н. Толстого: категория смерти в его религиозно-нравственной философии, [в:] „Вестник Московского университета”, сер. 7: Философия 2000, № 3, с. 84-98; Н. Шишхова, Конщепт смерти в повести Л. Н. Толстого „Смерть Ивана Ильича”, [в:] „Вестник Адыгейского государственного университета", сер. 2: Филология и искусствоведение 2011, № 3, с. 76-80. 
такие произведения писателя, как Три смерти (1859), Смерть Ивана Ильича (1886), Хозяин и работник (1895), романы Война и мир (1869) и Анна Каренина (1877); а также Детство (1852), Отрочество (1854), Набег (1853), Рубка леса (1855), Севастопольские рассказы (1855), Записки маркера (1855) и др. Наряду с художественными произведениями в поле внимания исследователей находятся и религиозно-философские сочинения Толстого, в которых затрагивается мортальная проблематика.

В центре данной статьи - толстовские размышления о смерти, выраженные в Исповеди (1879-1882) 9 . Сохранившиеся черновики, как отметил Николай Гусев, свидетельствуют о том, что в ранних вариантах новое произведение начиналось непосредственно

с описания душевного кризиса, пережитого автором [...] „Мне было почти 50 лет, когда со мной сделалось то ужасное душевное состояние, которое чуть не привело меня к самоубийству и наконец привело меня в то душевное состояние, в котором я нахожусь" $" 10$.

Впоследствии структура текста несколько изменилась, но тема мортальности осталась одной из ведущих. Появляется она в третьей главе Исповеди (всего их 16) в двух идущих один за другим эпизодах мемуарного характера. Постепенно тема мортальности расширяется, развивается, занимая основное пространство текста в IV-VII главах, затем несколько отходит в тень, но не исчезает вовсе. В первом эпизоде Толстой вспоминает, как он, находясь в своей первой заграничной поездке, 25 марта 1857 года, испытал настоящее потрясение, наблюдая гильотинирование убийцы в Париже. Сам „вид смертной казни” преступника („голова отделилась от тела, и то, и другое врозь застучало в ящике” [т. 16, с. 113]) в мирное время в европейской столице подействовал на писателя, имевшего к тому времени реальный опыт участия в военных действиях и слывшего храбрым офицером, крайне угнетающе. Второй эпизод связан со смертью старшего брата Николая Николаевича, который скончался на руках Льва Николаевича от туберкулеза 20 сентября 1860 года в Гиере во Франции. 13 октября 1860 года Толстой записал в дневнике: „[...] Николенька умер. Страшно оторвало меня от жизни это событие. Опять вопрос: зачем? [...] Николенькина смерть

9 См. об Исповеди работы последних лет: А. А. Балдин, „Исповедь” Л. Н. Толстого и его произведения 1880-1890-х г2., „Известия Уральского университета” 2000, № 17, с. 24-32; И. И. Виноградов, „Вопрос жизни” и мытарства „разумной веры” Льва Толстого, [в:] его же, Духовные искания русской литературы, Москва 2005, с. 56-143; Л. Луцевич, „Исповедь” Л. Н. Толстого: анализ, покаяние, поиски истины веры, „Slawia Orientalis” 2010, № 4, s. 467-486; С. Зассе, Заразительная речь против заразительного греха. Выступление Толстого против слабости, [в:] ее же, Яд в ухо: Исповедь и признание в русской литературе, пер. с нем. Б. Скуратова и И. Чубарова, Москва 2012, с. 133-165; А. Д. Зорина, Исповедальность Льва Толстого: путь к смыслу жизни, [в:] Лев Николаевич Толстой..., с. 206-218.

${ }^{10}$ Н. Н. Гусев, Комментарии. Исповедь, [в:] Л. Н. Толстой, Полное собрание сочинений: в 90 m., т. 23, подг. текста и ком. Н. Н. Гусева, Москва 1957, с. 518. 
— самое сильное впечатление в моей жизни" [т. 21, с. 231]. Это же впечатление почти через двадцать лет получит отражение в Исnоведи:

Умный, добрый, серьёзный человек, он заболел молодым, страдал более года и мучительно умер, не понимая, зачем он жил, и ещё менее понимая, зачем он умирает. Никакие теории ничего не могли ответить на эти вопросы ни мне, ни ему во время его медленного и мучительного умирания [т. 16, с. 113].

Тема смерти, ее гнетущее эмоциональное восприятие, „печоринские” вопросы: зачем человек жил? зачем умирает? - возникнув в этих двух мемуарных эпизодах, далее варьируются и умножаются.

Согласно воспоминаниям писателя, он уже в начале шестидесятых годов испытывал все возрастающее внутреннее беспокойство: „, я чувствовал, что я не совсем умственно здоров [...] я заболел более духовно, чем физически, - бросил всё и поехал в степь к башкирам - дышать воздухом, пить кумыс и жить животною жизнью” [т. 16, с. 114-115]. Толстой выехал на отдых в Самарскую губернию 14 мая 1862 году, вернулся, как считал, абсолютно здоровым 31 июля ${ }^{11}$. А 23 сентября 1862 года женился на Софье Берс. Семейное счастье отсрочило на 15 лет то „отчаяние”, к которому Толстой все же „пришёл в пятьдесят лет” [т. 16, с. 114]. Но и в период полного счастья случались события „необыкновенные”. Одно из них упоминается в письме к Софье Андреевне от 4 сентября 1869 года:

Третьего дня в ночь я ночевал в Арзамасе, и со мной было что-то необыкновенное. Было 2 часа ночи, я устал страшно, хотелось спать, и ничего не болело. Но вдруг на меня нашла тоска, страх, ужас такие, каких я никогда не испытывал. [...] подобного мучительного чувства я никогда не испытывал, и никому не дай бог испытать [т. 18 , c. 683].

Позже сын Толстого - Сергей Львович, напишет: „Я не берусь определить причину арзамасской тоски, но мне все-таки кажется, что это был болезненный припадок” ${ }^{2}$. Однако сам Толстой в письме отметил: „ничего не болело".

Приступы толстовских страхов спровоцировали появление множества работ, посвященных состоянию здоровья и так называемым „патологиям” писателя ${ }^{13}$. Известный врач-психиатр Григорий Сегалин (1878-1960), ис-

${ }^{11}$ См.: В. С. Морозов, Воспоминания о Л. Н. Толстом ученика яснополянской школь, [в:] Л. Н. Толстой в воспоминаниях современников: в 2 m, т. 2, Санкт-Петербург 2017, с. 127-136.

12 С. Л. Толстой, Очерки былого, Тула 1975, с. 28-29.

13 См.: Ч. Ломброзо, Мое посещение Толстого, Carouge (Geneve) 1902; Г. В. Сегалин, Эвропатология личности и творчества Льва Толстого, Свердловск 1930; Д. Ранкур-Лаферьер, Лев Толстой на кушетке психоаналитика. Женоненавистничество, мазохизм и ранняя утрата матери, [в:] его же, Русская литература и психоанализ, пер. Ю. Маслов, Москва 2004, с. 541-856; И. Сироткина, Толстой и зарождение психоанализа в России, [в:] ее же, Классики и психиатры. Психиатрия в российской культуре конца ХІХ-начала ХХ века, Москва 2008, с. 102-103; М. Баганова, Лев Толстой. Психоанализ гениального женоненавистника, Москва 2014. 
следовавший влияние болезней на творческий процесс писателя, безапелляционно заявлял: „Нет сомнения в том, что весь характер этих приступов «арзамасской тоски» не есть только простая фобия, а типичный эпилептический эквивалент эпилептика, сопровождающийся галлюцинациями"14. В Исповеди об арзамасском приступе нет ни слова. Толстой только отмечает участившиеся „странные” внутренние состояния:

[...] со мною стало случаться что-то очень странное: на меня стали находить минуты сначала недоумения, остановки жизни, как будто я не знал, как мне жить, что мне делать, и я терялся и впадал в уныние. [...] Эти остановки жизни выражались всегда одинаковыми вопросами: Зачем? Ну, а потом? [т. 16, с. 115].

Свое психическое состояние писатель сравнивает с ситуацией тяжело заболевшего человека:

Случилось то, что случается с каждым заболевающим смертельною внутреннею болезнью. Сначала появляются ничтожные признаки недомогания, на которые больной не обращает внимания, потом признаки эти повторяются чаще и чаще и сливаются в одно нераздельное по времени страдание. Страдание растёт, и больной не успеет оглянуться, как уже сознаёт, что то, что он принимал за недомогание, есть то, что для него значительнее всего в мире, что это - смерть [т. 16, с. 116].

Теперь Толстой уже не может с прежним рвением заботиться о семейном благосостоянии, ему каждый раз не дает покоя повторяющийся вопрос: зачем это делать? „Прежде чем заняться самарским имением, воспитанием сына, писанием книги, надо знать, зачем я это буду делать" [т. 16, с. 116], какой во всем этом смысл? Семен Франк отмечал: „мы знаем по Испове$\partial u$, что страх смерти значил у Толстого мистический ужас перед временным, преходящим характером жизни, ужас перед бессмысленностью всей жизни, если она [...] не прикреплена к чему-либо вечному"15. Но мы также знаем, что Толстой нашел в себе смелость отправиться в ужасное „путешествие" - в свой внутренний мир, где поселился страх — всепроникающий, ослепляющий, блокирующий сознание автора. Однако через опыт самовыражения этого страха автор продолжает процесс самопознания. Пережитое состояние душевного коллапса оставляет пессимистическое осознание только „этого одного”: движение человека к небытию предопределено, смерть неизбежна, значит, жизнь не имеет никакого смысла. Автор обреченно заключает: единственная истина, существующая в мире, состоит в том, что „жизнь есть бессмыслица”, что ничего нет впереди, кроме „[...] страданий и настоящей смерти — полного уничтожения” [т. 16, с. 117]. Бессмыслица жизни, потрясшая сознание писателя, кроется, по словам Василия Маклакова, в неизбежности смерти: „Для Толстого бессмыслица жизни была именно в том, что жизнь кончалась смертью, что не было ни

${ }^{14}$ Г. В. Сегалин, Эвропатология личности и творчества Льва Толстого, http://tolstoy. lit-info.ru/tolstoy/public/segalin-evropatologiya-lichnosti/index.htm [дата обращения: 30.06.2017].

15 С. Л. Франк, Памяти Льва Толстого (1910), [в:] Л. Н. Толстой: pro et contra .., с. 550. 
одного счастья, которое не уничтожалось бы смертью; это исходный пункт его мук"16. Действительно, испытывая состояние бессильного отчаяния, Толстой указывает на естественность и даже закономерность появления мысли о самоубийстве:

Мысль эта была так соблазнительна, что я должен был употреблять против себя хитрости, чтобы не привести её слишком поспешно в исполнение. [...] И вот тогда я, счастливый человек, вынес из своей комнаты, где я каждый вечер бывал один, раздеваясь, шнурок, чтобы не повеситься на перекладине между шкапами, и перестал ходить с ружьём на охоту, чтобы не соблазниться слишком лёгким способом избавления себя от жизни. Я сам не знал, чего я хочу: я боялся жизни, стремился прочь от неё и, между тем, чего-то ещё надеялся от неё [т. 16, с. 117].

Парадоксально, но факт: гнетущая депрессия возникла не в результате каких-либо травмирующих событий или непреодолимых трудностей в жизни писателя. Как раз наоборот; он переживал период „совершенного счастья":

У меня была добрая, любящая и любимая жена, хорошие дети, большое имение, которое без труда с моей стороны росло и увеличивалось. Я был уважаем близкими и знакомыми, больше чем когда-нибудь прежде, был восхваляем чужими и мог считать, что я имею известность, без особенного самообольщения. При этом я не только не был телесно или духовно нездоров, но, напротив, пользовался силой и духовной, и телесной, какую я редко встречал в своих сверстниках: телесно я мог работать на покосах, не отставая от мужиков; умственно я мог работать по восьми - десяти часов подряд, не испытывая от такого напряжения никаких последствий. И в таком положении я пришёл к тому, что не мог жить и, боясь смерти, должен был употреблять хитрости против себя, чтобы не лишить себя жизни [т. 16, с. 117-118].

Подавляющее состояние ужаса разрушало психику, ум и дух писателя. Рассматривая свои отдельные поступки, анализируя и оценивая свою жизнь в целом, он не может найти в них какой-либо смысл. Ему ясно только одно: „не нынче - завтра придут болезни, смерть [...] и ничего не останется” [т. 16, с. 118]. Отсюда вывод: положение человека „глупо и отчаянно”, „жизнь бессмысленна и ужасна” [т. 16, с. 120].

Но Толстой не может ограничиться только констатацией пережитого эмоционального потрясения, ему необходимо рассмотреть проблему глубже: то, что неоднократно повторяется, не может быть вызвано частным случаем или причудой, оно должно определяться какой-то причиной; „если повторяются всё те же вопросы, то надо ответить на них" [т. 16, с. 116]. Причем, как вспоминает писатель, поначалу ему казалось, что вопрос о смысле жизни банален и при надобности ответ на него будет найден без особого труда, просто пока ему „некогда этим заниматься” [т. 16, с. 116]. Априори он был убежден, что мир упорядочен и имеет смысл, поэтому поначалу проблема смысла жизни видится как нечто абстрактно-отдаленное и не имеющие места в настоящем. Но постепенно писатель все чаще соотносит пробле-

${ }^{16}$ В. А. Маклаков, О Льве Толстом. Две встречи, Paris 1929, с. 14. 
мы жизни с конечностью человеческого существования, т. е. с проблемой смерти. И это становится явлением непосредственного переживания уже в настоящем, от чего невозможно отмахнуться. Острое чувство непредолимого страха смерти, завладевшее сознанием, приводит автора в состояние полного оцепенения - „жизнь остановилась”. Новое ощущение требует соответствующего истолкования, постепенно приходит понимание того, что решение вопроса - есть ли в жизни такой смысл, который не уничтожался бы смертью? - единственная жизненно важная потребность. Для достижения результата необходим соответствующий метод, с помощью которого можно решить важнейший „,вопрос жизни”. И Толстой попытался воспользоваться наболее приемлемым, усвоенным с юности, - рационалистическим. Законы природы устанавливает познающий её человек и, кроме познания жизни разумом ${ }^{17}$, других способов не существует. Культ разума в XIX веке - явление общераспространенное. Один из современников писателя - Роман Дистерло, писал:

Привычная нам, господствовавшая в девятнадцатом столетии, рационалистическая философия [...] провозглашала верховенство [...] разума. Всю сферу сознательной жизни человека она подчиняла разуму и в нем видела единственное средство для удовлетворения всех духовных потребностей. Она признавала за истину только то, что можно было доказать из разума, что допускало логическую поверку ${ }^{18}$.

Самого Толстого, по его признанию, с ранней молодости привлекали разнообразные знания ${ }^{19}$ - „умозрительные”, ,математические”, „естественные” [т. 16, с. 122]. К ним-то и обратился уже маститый писатель, ища ответ на свой, „самый важный и глубокий вопрос в жизни” [т. 16, с. 116]. Но обнаружил только то,

что по отношению к этому вопросу все человеческие знания разделяются как бы на две противоположные полусферы, на двух противоположных концах которых находятся два полюса: один — отрицательный, другой — положительный [...].

Один ряд знаний как бы и не признаёт вопроса, но зато ясно и точно отвечает на свои независимо поставленные вопросы: это - ряд знаний опытных, и на крайней точке их стоит математика; другой ряд знаний признаёт вопрос, но не отвечает на него: это - ряд знаний умозрительных, и на крайней их точке - метафизика [т. 16, c. 122].

Суть „опытных знаний” писатель интерпретировал в русле современного ему антропогенеза, опирающегося на всеобщий закон развития природы: „Всё развивается, дифференцируется, идёт к усложнению и усовершенствованию, и есть законы, руководящие этим ходом” [т. 16, с. 122].

17 В своей первой дневниковой записи от 17 марта 1847 г. Толстой - студент Казанского университета - пишет о разуме как „первенствующей способности человека” [т. 21, с. 7].

18 Р. А. Дистерло, Граф Л. Н. Толстой как художник и моралист. Критический очерк, Санкт-Петербург 1887, с. 17-18.

1919 марта 1847 г. Толстой отмечает в дневнике: „Во мне начинает проявляться страсть к наукам" [т. 21, с. 8]. 
Физический и духовный мир для Толстого - это многоликое единое целое, человек является его частью, значит, познав „целое” и общий „закон развития”, человек познает „и самого себя” [т. 16, с. 122]. Наблюдая с молодости за процессом собственного роста и совершенствования - физического и интеллектуального - Толстой на собственном опыте убеждается, что человек развивается, как и вся природа ${ }^{20}$, по законам непрерывного усложнения. В зрелом возрасте, продолжая самонаблюдения, он обнаруживает в себе уже признаки распада - и тогда с негодованием отвергает всеобщий закон развития:

я почувствовал, что не развиваюсь, а ссыхаюсь, мускулы мои слабеют, зубы падают, и я увидал, что этот закон не только ничего мне не объясняет, но что и закона такого никогда не было и не могло быть, а что я принял за закон то, что нашёл в себе в известную пору жизни [т. 16, с. 123].

Противоречия, сомнения, неудовлетворенность существующим знанием обусловливали еще более настойчивое стремление писателя понять и объяснить себе, „что я такое с моими желаниями?” [т. 16, с. 123]. Константин Исупов утверждает, что „сознание Толстого работает в режиме дедукции: от картин жизни общечеловеческой к прозаическому быту частного лица"21. Однако в Исповеди такой однонаправленности нет, мы видим в рассуждениях писателя постоянное чередование, казалось бы, противоречащих друг другу методов и идей; здесь сознание писателя „работает” скорее амбивалентно - как в режиме дедукции, так и в режиме индукции. Он опирается на интеллектуальное, логическое, дедуктивное знание, а также на живое созерцание, стремясь объединить знания „опытные” (опробованные на практике) и „умозрительные” (теоретические).

Обращаясь к „разумному” знанию, здравому смыслу, писатель поначалу убежден, что на уровне теоретического знания он вполне сможет постичь суть интересующей его проблемы. Согласно его юношеским представлениям, естественнонаучная и философская рефлексии призваны выявлять объективные знания о жизни, систематизировать их, руководствуясь строгими критериями, формулировать всеобщие законы и объяснять их сущность. И вот уже зрелый Толстой, „мучительно и долго” ищет „во всех знаниях” объяснения на свои вопросы:

Я искал везде и, благодаря жизни, проведённой в учении, а также тому, что, по связям своим с миром учёным, мне были доступны сами учёные всех разнообразных отраслей знания, не отказывавшиеся открывать мне все свои знания не только в книгах, но и в беседах [т. 16, с. 121].

${ }^{20}$ Ср.: 17 апреля 1847 г. Толстой записал: „я прихожу всегда к одному заключению: цель жизни человека есть всевозможное способствование к всестороннему развитию всего существующего" [т. 21, с. 13-14].

${ }^{21}$ К. Г. Исупов, Чары троянского наследия..., с. 25. 
Писатель в качестве объекта исследования использует и самого себя: он досконально анализирует свои собственные познания, приобретённые в процессе непосредственных личных переживаний, впечатлений, практических действий, наблюдений и неустанных размышлений. Результат пессимистичен: „я не могу не видеть дня и ночи, бегущих и ведущих меня к смерти. Я вижу это одно, потому что это одно - истина. Остальное всё ложь" [т. 16, с. 119].

При всей, казалось бы, логической очевидности умозаключения, писатель все же не ограничивается личными наблюдениями и общением с „миром ученым”, он вновь обращается к конкретным „опытным” наукам физиологии, психологии, биологии. Однако, в его оценке, эти науки „исполнены неясностей, неточностей, глупостей и противоречий” [т. 16, с. 125], поэтому не заслуживают доверия. Но и науки „умозрительные” - метафизика, философия, а также науки юридические, социальные, исторические, по мнению писателя, или не отвечают на важнейшие вопросы бытия (что такое человек? что такое мир?), или сами только об этом и спрашивают: „вместо ответа получается тот же вопрос, только в усложнённой форме" [т. 16, с. 126]. Совершенно очевидно: суждения, характеристики, интерпретации, оценки наук, данные Толстым, носят личностный, пристрастный характер. Философия излишне, по его мнению, субъективно осмысляет устремления человека к безграничности и универсальности развития; она создает лишь некие неясные фрагменты картины мира, в которых человек всегда односторонне видит самого себя. Математика изучает слишком абстрактные понятия. Естественнонаучные дисциплины, наоборот, поглощены специальными знаниями: „о химическом составе звёзд, о движении солнца к созвездию Геркулеса, о происхождении видов и человека, о формах бесконечно малых атомов, о колебании бесконечно малых невесомых частиц эфира" [т. 16, с. 127].

Несмотря на растущий скептический нигилизм относительно возможности позитивного решения „вопроса жизни”, Толстой все еще не отказывается от рассудочного здравомыслия и предпринимает новую попытку погрузиться в высшую мудрость „сильнейших умов человечества”: в размышления Соломона, Сакиа-Муни, Сократа, Шопенгауэра ${ }^{22}$ о жизни и ее смысле, о смерти. Писатель ценит мудрость - как глубокое понимание логики происходящего в настоящем и способность предвидеть будущее выше интеллектуального знания. Результатом этого погружения во многовековую человеческую мудрость становится созданная Толстым типология, основу которой определяет отношение просвещенных людей к идее бессмысленности жизни как к установленной истине. Писатель формирует

22 См. об этом соответствующие главы из книги Давида Квитко: Смысл жизни; Толстовство и буддизм; Толстой и Шопенгауэр, [в:] Д. Ю. Квитко, Философия Толстого, Москва 1930, с. 1-23; с. 47-52, с. 95-100; И. А. Белая, Буддизм как теоретический источник учения сознания жизни Л. Н. Толстого, „Этическая мысль”, вып. 2, Москва 2001, с. 203-215; С. Валюлис, Лев Толстой и Артур Шопенгауэр, Вильнюс 2000. 
четыре „разряда” представителей современного ему образованного круга, где одни избирают позицию „неведения”, суть которой „не знать, не понимать того, что жизнь есть зло и бессмыслица"; другие опираются на эпикурейство: „зная безнадёжность жизни, пользуются [...] теми благами, какие есть”; третьи уповают на свою силу и энергию: „поняв, что жизнь есть зло и бессмыслица, уничтожают её”; четвертые остаются на позиции „слабости”: „понимая зло и бессмысленность жизни, продолжают тянуть её, зная вперёд, что ничего из неё выйти не может" [т. 16, с. 133-134]. Автор, по собственному признанию, находится в последнем - четвертом — разряде. Как видно, и общение с мудрейшими не изменило общего вывода.

Казалось бы, круг замкнулся: при имеющихся различиях в отношении к проблеме людей образованного класса объединяет понимание того, что жизнь есть зло и бессмыслица, и нет в ней такого смысла, который не уничтожался бы смертью. Однако при наличии всей так называемой „тяжелой артиллерии" несомненных доказательств в пользу бессмысленности жизни у автора все же теплилось „смутное сознание несправедливости” этих размышлений, и его беспокоил вопрос: „,а что как я чего-нибудь ещё не знаю?” [т. 16, с. 136]. Под влиянием этого сознания он дает волю развитию своих мыслей в новом направлении — в направлении „неразумного знания”, то есть веры [т. 16, с. 138]. Вопросам поиска и обретения веры посвящена вторая часть Исповеди, где описано, как „Толстой нашел веру, пережил глубокий религиозный опыт, ощутил Бога, - и этот новый опыт дал ему возможность существовать" 23 далее.

\section{Библиография}

Баганова М., Лев Толстой. Психоанализ гениального женоненавистника, Москва 2014.

Балдин А. А., «Исповедь» Л. Н. Толстого и его произведения 1880-1890-х г2., „Известия Уральского университета" 2000, № 17.

Белая И. А., Буддизм как теоретический источник учения сознания жизни Л. Н. Толстого, „Этическая мысль”, вып. 2, Москва 2001.

Бердяев Н. А., Ветхий и Новый Завет в религиозном сознании Л. Толстого, [в:] Л. Н. Толстой: pro et contra. Личность и творчество Льва Толстого в оценке русских мыслителей и исследователей, сост., вступ. ст., коммент, и библиогр. К. Г. Исупова, Санкт-Петербург 2000.

Бирюков П. И., Биография Л. Н. Толстого: в 2 кн., кн. І, Москва 2000.

Бицилли П., Проблема смерти в творчестве Толстого, [в:] Л. Н. Толстой: pro et contra. Личность и творчество Льва Толстого в оиенке русских мыслителей и исследователей, сост., вступ. ст., коммент, и библиогр. К. Г., Исупова, Санкт-Петербург 2000.

Булгаков С. Н., Человекобог и человекозверь. По поводу последних произведений Л. Н. Толстого: „Дьявол” и „Отеи Сергий”, [в:] Л. Н. Толстой: pro et contra. Личность и творчество Льва Толстого в оиенке русских мыслителей и исследователей, сост., вступ. ст., коммент, и библиогр. К. Г. Исупова, Санкт-Петербург 2000.

23 В. В. Зеньковский, Проблема бессмертия у Л. Н. Толстого, [в:] О религии Льва Толстого, Москва 1912, с. 33-34. 
Валюлис С., Лев Толстой и Артур Шопенгауэр, Вильнюс 2000.

Виноградов И. И., Духовные искания русской литературы, Москва 2005.

Волохова Н., „Путь смерти” Л. Н. Толстого: категория смерти в его религиозно-нравственной философии, „Вестник Московского университета”, сер. 7: Философия 2000, № 3.

Галаган Г., Путь Толстого к „Исповеди”, „Русская литература” 1978, № 3.

Гусев Н. Н., Комментарии. Исповедь, [в:] Л. Н. Толстой, Полное собрание сочинений: в 90 m., т. 23, подгот. текста и ком. Н. Н. Гусева, Москва 1957.

Демичев А., Дискурсы смерти. Введение в философскую танатологию, Санкт-Петербург 1997.

Дистерло Р. А., Граф Л. Н. Толстой как художник и моралист. Критический очерк, СанктПетербург 1887.

Зеньковский В. В., Проблема бессмертия у Л. Н. Толстого, [в:] О религии Льва Толстого, Москва 1912.

Зассе С., Яд в ухо: Исповедь и признание в русской литературе, пер. Б. Скуратова и И. Чубарова, Москва 2012.

Зорина А. Д., Исповедальность Льва Толстого: путь к смыслу жизни, [в:] Лев Николаевич Толстой, ред. А. А. Гусейнов, Т. Г. Щедрина, Москва 2014.

Ильин В. Н., Миросозериание графа Льва Николаевича Толстого и его место в истории философии XIХ века, предисл., коммент. К. Г. Исупов, Санкт-Петербург 2000.

Исупов К. Г., Русская философская танатология, „Вопросы философии” 1994, № 3.

Исупов К. Г., Русская философия смерти (ХVIII-ХХ в6.), [в:] Русская философия смерти: антология, сост., вступ. ст., коммент. его же, Москва; Санкт-Петербург 2012.

Исупов К. Г., Чары троянского наследия: Лев Толстой в пространствах приязни и неприятия, [в:] Лев Николаевич Толстой, ред. А. А. Гусейнов, Т. Г. Щедрина, Москва 2014.

Квитко Д. Ю., Философия Толстого, Москва 1930.

Красильников Р. Л., Танатологические мотивы в художественной литературе (Введение в литературоведческую танатологию), Москва 2015.

Ломброзо Ч., Мое посещение Толстого, Carouge (Geneve) 1902.

Луцевич Л., ,, Исповедь” Л. Н. Толстого: анализ, покаяние, поиски истины веры, „, Slawia Orientalis" 2010, № 4.

Маклаков В. А., О Льве Толстом. Две встречи, Paris 1929.

Мейлах Б., Уход и смерть Льва Толстого, Москва-Ленинград 1960.

Мережковский Д. С., Л. Толстой и Достоевский, подг. Е. А. Андрущенко, Москва 2000.

Меситова С., Этическая танатология Л. Н. Толстого: Толстовский опыт переживания смерти и его нравственно-религиозный смысл, Диссертация на соискание ученой степени кандидата философских наук, Тула 2003.

Минеев В., Социальные аспекты смерти (философско-антропологический анализ), Москва 2014.

Морозов В. С., Воспоминания о Л. Н. Толстом ученика яснополянской школь, [в:] Л. Н. Толстой в воспоминаниях современников: в 2 m, т. 2, Санкт-Петербург 2017.

Мортальность в литературе и культуре: ред. А. Г. Степанов, В. Ю. Лебедев, Москва 2015.

Нагина К., Образно-смысловая оппозиция „жизнь”-,смерть” в произведениях Л. Н. Толстого 1880-х годов, Автореферат на соискание ученой степени кандидата филологических наук, Воронеж 1998.

Опульская Л. Д., Позднее творчество Л. Н. Толстого, [в:] Л. Н. Толстой, сост. А. И. Шифман, под общ. ред. Д. Д. Благого, Москва 1955.

Попов Г., Проблема жизни и смерти в религиозно-философской антропологии Л. Н. Толстого, Автореферат на соискание ученой степени кандидата филологических наук, Москва 2006.

Ранкур-Лаферьер Д., Русская литература и психоанализ, перев. Ю. Маслов, Москва 2004.

Сегалин Г.В., Эвропатология личности и творчества Льва Толстого, Свердловск 1930, http:// tolstoy.lit-info.ru/tolstoy/public/segalin-evropatologiya-lichnosti/index.htm.

Slavica Wratislaviensia 167, 2018

(C) for this edition by CNS 
Семикина Ю., Художественная танатология в творчестве Л. Н. Толстого 1850-1880-х гz.: Образы и мотивы, Автореферат диссертации на соискание ученой степени кандидата филологических наук, Волгоград 2002.

Сироткина И., Классики и психиатры. Психиатрия в российской культуре конца XIX-начала ХХ века, Москва 2008.

Степун Ф. А., Религиозная трагедия Льва Толстого, [в:] Л. Н. Толстой: pro et contra. Личность и творчество Льва Толстого в оченке русских мыслителей и исследователей, сост., вступ. ст., коммент, и библиогр. К. Г. Исупова, Санкт-Петербург 2000.

Толстой Л. Н., Полное собрание сочинений: в 90 m., общ. ред. В. Г. Черткова, Москва 19281964; т. 17: 1936; т. 23, 1957.

Толстой Л. Н., Собрание сочинений: в 22 m., гл. ред. М. Б. Храпченко, Москва 1978-1985; т. 16,$1983 ;$ т. $21,1985$.

Толстой С. Л., Очерки былого, Тула 1975.

Франк С. Л., Памяти Льва Толстого (1910), [в:] Л. Н. Толстой: pro et contra. Личность и творчество Льва Толстого в оченке русских мыслителей и исследователей, сост., вступ. ст., коммент, и библиогр. К. Г. Исупова, Санкт-Петербург 2000.

Хагурова Н., Проблема смысла жизни и смерти в философии Л. Н. Толстого, Автореферат диссертации на соискание ученой степени кандидата философских наук, Москва 1995.

Шестов Л., Откровения смерти. (Последние произведения Л. Н. Толстого), „Современные Записки" 1920, № 1 (Париж).

Шишхова Н., Кониепт смерти в повести Л. Н. Толстого “Смерть Ивана Ильича”, „Вестник Адыгейского государственного университета”, сер. 2: Филология и искусствоведение 2011, № 3.

Шкловский В., Лев Толстой, Москва 1963.

Эйхенбаум Б., Лев Толстой: семидесятые годы, Ленинград 1960.

\section{"Does my life have a meaning that wouldn't be destroyed by my inevitably approaching death?" Confessional reflections on death of Leo Tolstoy}

\section{Summary}

The search for the meaning of life, contributing to the dramatic changes that have occurred in the philosophy and work of Leo Tolstoy, has been reflected in his Confession (1879-1882). The theme of death first appears in the third chapter of the Confession, among the episodes that represent memoirs, and then expands, occupying the main space in the IV-VII chapters. In his memoirs, trying to get a trustworthy answer to the question that tortures him, the writer uses methods of experiential and theoretical sciences. As a result, he comes to the conclusion that life is meaningless and creates a four-part typology. Only taking the path of "irrational knowledge" that is faith, and having experienced a deep religious understanding, he creates a doctrine that makes the sense of life.

Keywords: Leo Tolstoy, death, empiricism, speculative sciences, faith 


\section{„Czy jest w życiu mem cel, któregoby nie zniszczyła nieunikniona, czekająca śmierć?” - rozmyślania Lwa Tołstoja o śmierci}

\section{Streszczenie}

Poszukiwanie sensu życia, będące przyczyną kardynalnych zmian, jakie nastąpiły w światopoglądzie i twórczości Lwa Tołstoja, znalazło swoje odzwierciedlenie w jego Spowiedzi (1879-1882). Temat śmierci po raz pierwszy pojawia się w III rozdziale dzieła, w części mającej charakter pamiętnikarski, a następnie rozwija się, stanowiąc zasadniczą treść rozdziałów IV-VII. Pisarz, starając się uzyskać wiarygodną odpowiedź na dręczące go pytanie, w swoich rozważaniach ucieka się do metod nauk empirycznych i spekulatywnych. W efekcie dochodzi do wniosku o bezsensowności życia i tworzy czteroczęściową typologię. Dopiero po wejściu na ścieżkę „wiedzy nierozsądnej” — wiary, doświadczając głębokiego doznania religijnego, Tołstoj tworzy doktrynę, zgodnie z którą odnajduje sens życia.

Słowa kluczowe: Lew Tołstoj, śmierć, empiryzm, nauki spekulatywne, wiara 